\title{
Analytical Hierarchy Process for Regional Development Priority in Maluku Province, Indonesia
}

\author{
Lia Amellya Larasati ${ }^{1}$, Nur Medisyanning Khoiruluswati ${ }^{1}$, Rizki Rahmi Aliyya ${ }^{1}$, Unggul Widyanarko ${ }^{1}$, and Ratih \\ Fitria Putri ${ }^{1 *}$
}

${ }^{1}$ Department of Environmental Geography, Faculty of Geography, Universitas Gadjah Mada, Jalan Sekip Utara, Bulaksumur, Yogyakarta 55281, Indonesia

*Corresponding author: ratihfitria.putri@ugm.ac.id

\section{KEYWORDS}

AHP

Decision-making

Human development

Maluku

Regional development

\begin{abstract}
Maluku is one of the provinces of the eastern part of Indonesia, consisting of 11 regencies. The Maluku branch of Statistics Indonesia reported in 2018 that in 2013-2018 the number of poor people in Maluku's rural areas increased by 1,970. Concurrently, the number of poor people in urban areas decreased by around 6,070 people. This fact showed that development in Maluku Province hadn't been implemented effectively and equally. This study aimed to determine the development priority in Maluku Province using the Analytical Hierarchy Process method. The determination of priorities was based on three aspects in the human development index concept, namely education, health, and economy. Data from Statistics Indonesia on life expectancy, mean years of schooling, expected years of schooling, and per capita expenditure were the indicators were used as the indicators in this study. The results showed that there were 10 regencies with a high level of priority, with the exception being Ambon City, which had a low-level priority. Classification of regencies showed that there was a disparity between them. These findings can help to inform future development designs in Maluku Province.
\end{abstract}

(c) The Author(s) 2019. This article is distributed under a Creative Commons Attribution-ShareAlike 4.0 International license.

\section{INTRODUCTION}

A population, according to Jain and Jain (2016), has an impact on environmental deterioration, though it cannot be linked directly because it's not simply due to population growth. The population also has an important influence on development because of its roles as a development agent and target (Putri et al. 2018). One of the Indonesian government's efforts to enable its population to have more life choices is to improve quality through human development (Putri et al. 2019). Population welfare is one of the benefits of developing human quality, the skills from which, beyond being bestowed on individuals, can lead to empowerment and enlarge their life choices (Yilmazer and Çinar 2015). Elements that are contained within human development include productivity, equality, sustainability, and empowerment, and these elements are measured with three important pillars that cannot be separated-education, health, and economics (Mohanty et al. 2016). These three aspects need to be improved when the goal is better human quality.

Maluku Province is one of the regions in Eastern Indonesia. It consists of 11 regencies. Geographically, Maluku is composed of an arc-shaped chain of islands separated by the Banda Sea. One of the economic problems in Maluku Province is poverty. The number of poor people in rural areas during the period of 2013-2018 increased by 1,970 people (from 45,890 to 47,860 people), while the number of poor people in urban areas decreased by around 6,070 people (from 274,190 to 268,120 people) (Statistics Indonesia 2018b). These figures show that development efforts in Maluku Province have not been implemented effectively and evenly. A study focused on determining development priorities in Maluku based on the three pillars of human development is therefore essential.

The human development index (HDI) is an indicator of human development based on basic components of quality of life. This component was built through a threedimensional basic approach that includes opportunities for living a long and healthy life, knowledge, and decent living standards based on people's purchasing power parity (Statistics Indonesia 2017). Operationally, the size of development efforts is based on the three-dimensional measurements of (1) life opportunities, measured in life expectancy (LE); (2) knowledge, measured in mean years of schooling (MYS) and expected years of schooling (EYS); and (3) decent living standards, measured in average adjusted real per capita expenditure (PCE).

The concept of human development involves providing economic security, as well as increasing the opportunity of others to fulfill their rights and make their choices freely with an empowering effort, such as in education and health. The main objective of development is to create an environment that enables people to enjoy a long life, lived in good health and productively. Development is concerned with equality, sustainability, and empowerment. The HDI is one of the indices used as a benchmark for comparing development between one region and another (Nevima and Kiszova 2017). HDI gaps between regions reflect the government's success in achieving its goals, along with its readiness to face globalization (Hardianto et al. 2018). 
The Analytical Hierarchy Process (AHP) is one of the methods used in decision-making and prioritization. The working steps of this model involve describing complex multi-factor or multi-criteria problems and then systematically compiling them into a hierarchy (Sipahi and Timor 2010). The criteria that have been chosen and systematically grouped are the result of the understanding, beliefs, and values of individuals as decision-makers. This model consequently is a method of making a decision by grouping the criteria with a systematic approach based on human perception. The outline of this method has three steps: 1) determining the hierarchy, which is made from a "based on the purpose" structure; 2) pairwise comparison between criteria to another criterion; and 3) verification of the consistency of the weighted value (Darko et al. 2018).

This model is usually preferred in problem-solving compared with other methods for the following reasons (Mu and Pereyra-Rojas 2017): (a) the process is relatively easy, only needing a comparison between elements; (b) the hierarchical priority structure is a result of grouping the criteria, sub-criteria, or the in-depth sub-criteria and alternatives, making it easy to analyze the criteria and alternatives to achieve the goal; (c) calculating the validity up to the tolerance limit of inconsistencies in various criteria or alternatives; and (d) calculating the output durability of decision-making analysis. Indicators from the HDI have different effects so that calculating with different priorities is necessary. Based on these considerations, the aim of this study was to determine the development priority in Maluku Province based on the human development index indicators using the Analytical Hierarchy Process method.

\section{METHODS}

The Analytical Hierarchy Process is not an exact measurement method, but rather a relative measure used for comparing a number of criteria that have been chosen to obtain a priority index (Brunelli 2015). The poverty element was used in this research, which itself was based on three dimensions, namely health, knowledge, and economy (UNDP 2015). The criteria from the HDI dimension that we used were based on data provided by Statistics Indonesia. These data used in this study were secondary data from 2017, obtained from the Statistics Indonesia website regarding the human development index, which contained figures on life expectancy at birth, mean years of schooling, expected years of schooling, and per capita expenditure that were used as the indicators (Statistics Indonesia 2018a).

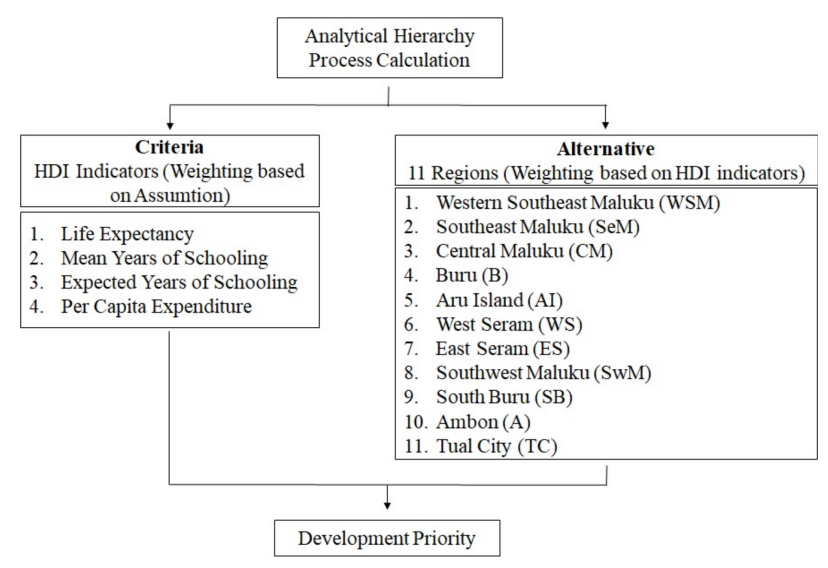

FIGURE 1. AHP structure that contains the criteria and alternatives.
The analysis was carried out using the aforementioned four indicators from the HDI, calculating them using the AHP method, and they are also referred to as criteria. The calculation using the AHP method was conducted on 11 regencies in Maluku Province, which are also referred to as the alternatives. The calculation of the alternatives was performed four times, comparing every regency based on their LE, MYS, EYS, and PCE. The results from these steps were weighted criteria and weighted alternatives based on four indicators. The weight from the criteria became a priority index which was multiplied with the alternatives. The AHP structure of this research is shown in Figure 1.

An effective way to overcome the development priority from the structure is to make a criterion that is obtained from the HDI dimension into a pairwise comparison. The calculation in this study was based on the Analytical Hierarchy Process method (Saaty 2012). The first thing to do in calculating AHP is to give values to the criteria based on our decision into a pairwise comparison matrix, the result of which is shown in Table 1, and which also shows the real values based on the authors' decision.

If $w_{i j}$ expressed is $i$ as the column and $j$ as the row, then the lower matrix could be filled with Equation 1:

$$
w_{i j}=\frac{1}{w_{i j}}
$$

TABLE 1. Giving weight to every indicator.

\begin{tabular}{lllll}
\hline Indicator & PCE (a1) & MYS (a2) & EYS (a3) & LE (a4) \\
\hline PCE (a1) & $1(\mathrm{a} 1,1)$ & $1 / 2(\mathrm{a} 1,2)$ & $1 / 3(\mathrm{a} 1,3)$ & $1 / 6(\mathrm{a} 1,4)$ \\
MYS (a2) & & $1(\mathrm{a} 2,2)$ & $1 / 2(\mathrm{a} 2,3)$ & $1 / 5(\mathrm{a} 2,4)$ \\
EYS (a3) & & $1(\mathrm{a} 3,3)$ & $1 / 3(\mathrm{a} 3,4)$ \\
LE (a4) & & & $1(\mathrm{a} 4,4)$ \\
\hline
\end{tabular}

TABLE 2. Weight calculation.

\begin{tabular}{lllll}
\hline Indicator & PCE (a1) & MYS (a2) & EYS (a3) & LE (a4) \\
\hline PCE (a1) & $1(\mathrm{a} 1,1)$ & $1 / 2(\mathrm{a} 1,2)$ & $1 / 3(\mathrm{a} 1$ & $1 / 6(\mathrm{a} 1,4)$ \\
MYS (a2) & $2(1 / \mathrm{a} 1,2)$ & $1(\mathrm{a} 2,2)$ & $1 / 2(\mathrm{a} 2,3)$ & $1 / 5(\mathrm{a} 2,4)$ \\
EYS (a3) & $3(1 / \mathrm{a} 1,3)$ & $2(1 / \mathrm{a} 3,2)$ & $1(\mathrm{a} 3,3)$ & $1 / 3(\mathrm{a} 3,4)$ \\
LE (a4) & $6(1 / \mathrm{a} 1,4)$ & $5(1 / \mathrm{a} 2,4)$ & $3(1 / \mathrm{a} 4,3)$ & $1(\mathrm{a} 4,4)$ \\
\hline
\end{tabular}

TABLE 3. The calculation of total weighted indicators.

\begin{tabular}{lllll}
\hline Indicator & PCE (a1) & MYS (a2) & EYS (a3) & LE (a4) \\
\hline PCE & 1 & $1 / 2$ & $1 / 3$ & $1 / 6$ \\
MYS & 2 & 1 & $1 / 2$ & $1 / 5$ \\
EYS & 3 & 2 & 1 & $1 / 3$ \\
LE & 6 & 5 & 3 & 1 \\
Column & 12 & $17 / 2$ & $29 / 6$ & $51 / 30$ \\
Totals & & & & \\
\hline
\end{tabular}

TABLE 4. Normalized table.

\begin{tabular}{lllll}
\hline Indicator & PCE (a1) & MYS (a2) & EYS (a3) & LE (a4) \\
\hline PCE & $\mathbf{1 / 1 2}$ & $2 / 34$ & $6 / 87$ & $30 / 306$ \\
MYS & $2 / 12$ & $\mathbf{2 / 1 7}$ & $6 / 58$ & $30 / 255$ \\
EYS & $3 / 12$ & $4 / 17$ & $\mathbf{6 / 2 9}$ & $30 / 153$ \\
LE & $6 / 12$ & $10 / 17$ & $18 / 29$ & $\mathbf{3 0 / 5 1}$ \\
\hline
\end{tabular}


The table can then be completed (Table 2). After acquiring the value for the lower matrix, each column is summed up (Table 3). The table must then be normalized by dividing each value with the sum result, which results in Table 4 .

The final result of the normalized table can be obtained by averaging across the rows in Table 5 . This calculation was the weighted criteria and showed priority between the four indicators. Table 5 shows that life expectancy (LE) had the highest influence and per capita expenditure (PCE) had the lowest influence for determining human quality.

From the obtained value, it was impossible that there were inconsistencies in the final matrix of judgments. To avoid these inconsistencies, it is necessary to calculate the consistency ratio (CR) by comparing the consistency index (CI) versus the random-like matrix (RI). The tolerance limit of the consistency ratio (CR) was $10 \%$; if the value was more than $10 \%$, it could not be used. The random-like matrix was constant and for calculating the criteria comparison 0.9 was used, while for the alternatives, a comparison of 1.52 was used. Calculating the consistency index used the formula shown in Equation 2.

$$
\mathrm{CI}=\frac{\left(\lambda_{\max }-n\right)}{n-1}
$$

However, to know the max, a calculation between the weighted sum (Table 5) with the bold value in Table 4 is required (Equation 3).

$$
\lambda_{\max }=\left[\begin{array}{r}
0.077 /(1 / 12)+0.126 /(2 / 17) \\
+0.222 /(6 / 29)+0.574 /(30 / 51) \\
4
\end{array}\right]
$$

The consistency index is shown in Equation 4.

TABLE 5. Calculating final weight.

\begin{tabular}{lll}
\hline Indicator & Calculation & Weight \\
\hline PCE & $(1 / 12+2 / 34+6 / 87+30 / 306) / 4$ & 0.077 \\
MYS & $(2 / 12+2 / 17+6 / 58+30 / 255) / 4$ & 0.126 \\
EYS & $(3 / 12+4 / 17+6 / 29+30 / 153) / 4$ & 0.222 \\
LE & $(6 / 12+10 / 17+18 / 29+30 / 51) / 4$ & 0.574 \\
\hline
\end{tabular}

$$
\mathrm{CI}=\frac{(4.05-4)}{(4-1)}=0.017032436
$$

The consistency ratio can be calculated using the formula shown in Equation 5.

$$
\begin{aligned}
\mathrm{CR} & =(\mathrm{CI} / \mathrm{RI}) \times 100 \% \\
& =(0.017 / 0.9) \times 100 \% \\
& =1.89 \% \sim 2 \%
\end{aligned}
$$

This calculation was performed again to compare the regencies based on the HDI indicators, and the final results were weighted alternatives. Per capita expenditure is shown in Table 6, mean years of schooling in Table 7, expected years of schooling in Table 8, and life expectancy is shown in Table 9. Each table contains the value that has been given with the final weight for every regency. These two weighted values need to be calculate again to obtain the development priority, which was the weighted alternatives multiplied with the weighted criteria.

\section{RESULTS AND DISCUSSION}

\subsection{Regional development parameters}

The regional development priority in Maluku Province was determined based on four parameters using the AHP method. If a given parameter is higher than another score, it will have a greater impact on determining development priorities. Life expectancy had the highest score because health has a fundamental role in human life, in addition to affecting the physical and mental health of people (Tsaurkubule 2014). The life expectancy index is also the most important factor among other criteria based on the correlation test conducted by (Yakunina and Bychkov 2015). The higher the life expectancy, the better the degree of public health, so that productivity can increase.

Mean years of schooling has a higher score in determining development priorities compared with expected years of schooling, with the former showing the level of educa-

\begin{tabular}{|c|c|c|c|c|c|c|c|c|c|c|c|c|c|}
\hline PCE & WSM & SeM & CM & B & $\mathrm{Al}$ & WS & ES & SwM & SB & $A$ & $\mathrm{TC}$ & Weight & Calculation result \\
\hline WSM & 1 & 0.5 & 0.333 & 0.25 & 0.5 & 0.5 & 0.333 & 1 & 0.5 & 0.143 & 0.5 & 0.041 & $\lambda_{\max }$ \\
\hline SeM & 2 & 1 & 0.333 & 0.333 & 1 & 0.5 & 0.5 & 2 & 1 & 0.167 & 1 & 0.047 & 11.218 \\
\hline CM & 3 & 3 & 1 & 1 & 2 & 2 & 1 & 3 & 2 & 0.333 & 3 & 0.139 & \\
\hline B & 4 & 3 & 1 & 1 & 3 & 2 & 2 & 4 & 3 & 0.333 & 3 & 0.061 & $\mathrm{Cl}$ \\
\hline $\mathrm{Al}$ & 2 & 1 & 0.5 & 0.333 & 1 & 0.5 & 0.5 & 2 & 1 & 0.167 & 1 & 0.033 & 0.021 \\
\hline WS & 2 & 2 & 0.5 & 0.5 & 2 & 1 & 0.5 & 2 & 2 & 0.2 & 2 & 0.087 & \\
\hline ES & 3 & 2 & 1 & 0.5 & 2 & 2 & 1 & 3 & 2 & 0.333 & 2 & 0.041 & CR \\
\hline SwM & 1 & 0.5 & 0.333 & 0.25 & 0.5 & 0.5 & 0.333 & 1 & 0.5 & 0.143 & 0.5 & 0.032 & 0.014 \\
\hline SB & 2 & 1 & 0.5 & 0.333 & 1 & 0.5 & 0.5 & 2 & 1 & 0.167 & 1 & 0.035 & \\
\hline A & 7 & 6 & 3 & 3 & 6 & 5 & 3 & 7 & 6 & 1 & 6 & 0.292 & Consistency \\
\hline TC & 2 & 1 & 0.333 & 0.333 & 1 & 0.5 & 0.5 & 2 & 1 & 0.167 & 1 & 0.191 & $1 \%$ \\
\hline Totals & 29 & 21 & 8.833 & 7.833 & 20 & 15 & 10.167 & 29 & 20 & 3.152 & 21 & & Weight 0.077 \\
\hline
\end{tabular}
tion that has been obtained while the latter indicates a person's opportunity to receive an education. Per capita expenditure has the lowest score because a person's economic condition depends on the quality of their health and education (Hanushek 2011; Finkelstein et al. 2013).

TABLE 6. The calculation for the per capita expenditure indicator. 
TABLE 7. The calculation for the mean years of schooling indicator.

\begin{tabular}{|c|c|c|c|c|c|c|c|c|c|c|c|c|c|}
\hline PCE & WSM & SeM & $\mathrm{CM}$ & B & Al & WS & ES & SwM & SB & A & $\mathrm{TC}$ & Weight & Calculation result \\
\hline WSM & 1 & 1 & 1 & 3 & 2 & 2 & 3 & 3 & 4 & 0.2 & 0.5 & 0.091 & $\lambda \max$ \\
\hline SeM & 1 & 1 & 1 & 3 & 2 & 2 & 3 & 3 & 5 & 0.2 & 0.5 & 0.093 & 11.31 \\
\hline CM & 1 & 1 & 1 & 3 & 2 & 2 & 3 & 3 & 5 & 0.2 & 0.5 & 0.093 & \\
\hline B & 0.333 & 0.333 & 0.333 & 1 & 1 & 1 & 1 & 1 & 2 & 0.125 & 0.3 & 0.038 & $\mathrm{Cl}$ \\
\hline Al & 0.5 & 0.5 & 0.5 & 1 & 1 & 1 & 2 & 1 & 3 & 0.143 & 0.3 & 0.048 & 0.031 \\
\hline WS & 0.5 & 0.5 & 0.5 & 1 & 1 & 1 & 2 & 1 & 3 & 0.143 & 0.3 & 0.048 & \\
\hline ES & 0.333 & 0.333 & 0.333 & 1 & 0.5 & 0.5 & 1 & 1 & 2 & 0.125 & 0.3 & 0.033 & $\mathrm{CR}$ \\
\hline SwM & 0.333 & 0.333 & 0.333 & 1 & 1 & 1 & 1 & 1 & 2 & 0.125 & 0.3 & 0.038 & 0.2 \\
\hline SB & 0.25 & 0.2 & 0.2 & 0.5 & 0.3 & 0.33 & 0.5 & 0.5 & 1 & 0.111 & 0.2 & 0.021 & \\
\hline A & 5 & 5 & 5 & 8 & 7 & 7 & 8 & 8 & 9 & 1 & 4 & 0.352 & Consistency \\
\hline TC & 2 & 2 & 2 & 4 & 3 & 3 & 4 & 4 & 6 & 0.25 & 1 & 0.144 & $2 \%$ \\
\hline Totals & 12.25 & 12.2 & 12.2 & 26.5 & 21 & 20.8 & 28.5 & 26.5 & 42 & 2.622 & 8.1 & \multicolumn{2}{|c|}{ MYS Weight 0.222} \\
\hline
\end{tabular}

TABLE 8. The calculation for the expected years of schooling indicator.

\begin{tabular}{|c|c|c|c|c|c|c|c|c|c|c|c|c|c|}
\hline PCE & WSM & SeM & CM & B & Al & WS & ES & SwM & SB & $A$ & $\mathrm{TC}$ & Weight & Calculation result \\
\hline WSM & 1 & 1 & 0.25 & 0.5 & 0.5 & 2 & 0.33 & 1 & 1 & 0.125 & 0.3 & 0.147 & $\lambda \max$ \\
\hline SeM & 1 & 1 & 0.33 & 1 & 2 & 0.5 & 1 & 2 & 1 & 0.14 & 0.3 & 0.097 & 12.36 \\
\hline CM & 4 & 3 & 1 & 3 & 5 & 2 & 4 & 4 & 3 & 0.25 & 1 & 0.034 & \\
\hline B & 2 & 1 & 0.33 & 1 & 2 & 0.5 & 2 & 2 & 2 & 0.17 & 0.5 & 0.077 & $\mathrm{Cl}$ \\
\hline Al & 2 & 0.5 & 0.2 & 0.5 & 1 & 0.25 & 1 & 1 & 1 & 0.11 & 0.2 & 0.143 & 0.136 \\
\hline WS & 0.5 & 2 & 0.5 & 2 & 4 & 1 & 3 & 3 & 3 & 0.2 & 0.5 & 0.07 & \\
\hline ES & 3 & 1 & 0.25 & 0.5 & 1 & 0.33 & 1 & 1 & 1 & 0.125 & 0.3 & 0.121 & CR \\
\hline SwM & 1 & 0.5 & 0.25 & 0.5 & 1 & 0.33 & 1 & 1 & 1 & 0.11 & 0.3 & 0.139 & 1.089 \\
\hline SB & 1 & 1 & 0.33 & 0.5 & 1 & 0.33 & 1 & 1 & 1 & 0.125 & 0.3 & 0.12 & \\
\hline A & 8 & 7 & 4 & 6 & 9 & 5 & 8 & 9 & 8 & 1 & 0.3 & 0.023 & Consistency \\
\hline TC & 4 & 3 & 1 & 2 & 5 & 2 & 4 & 4 & 4 & 4 & 1 & 0.029 & $8 \%$ \\
\hline Totals & 27.5 & 21 & 8.45 & 17.5 & 32 & 14.3 & 26.33 & 29 & 26 & 6.36 & 4.8 & & Weight 0.126 \\
\hline
\end{tabular}

\subsection{Regional development priorities}

The weighting result was the development value, which was obtained by multiplying the weighted criteria with the alternatives. The development value was then classified into three classes: low, medium, and high (Table 10). The classified value was to determine the development priorities of each city.

Figure 2 shows the development priority and each classification based on the previous calculation. Ambon City was the only one regency with a low development priority in Maluku Province based on the classification. The isogram shows that there was not a significant difference between the remaining 10 regencies with a high priority. This indicates a large gap in Maluku Province, because the HDI value of Ambon City was almost twice that of the other HDI values and the other regencies were all classified as having a high priority. Ambon City was the only area to have a low priority level, which suggests it has a good human quality. This was caused by the position of Ambon City as the provincial capital, which enables it to have various kinds of service centers such as health, education, economy, and governmental centers.

The causes of this significant gap are numerous, and include connectivity, either from inter-Maluku Regencies or between Maluku Regencies and outside Maluku Regencies. Maluku Province is an archipelago province with many small islands, which has been a challenge for the government. Figure 3 shows the distribution of development priorities, and proves that not only the connectivity between Maluku Regencies but inter-Maluku Regencies, as well. East Seram, having the highest development priority, has a small island in its western part (Figure 3a), while that Aru Island is surrounded by small islands that are categorized as part of the Aru Island boundary (Figure 3b). Southwest Maluku, shown in Figure 3c, also has a small island that is far enough from the big island.

Figure 4 shows that Ambon City had a high value in all parameters, while the rest of other regencies in Maluku Province had low values for some parameters, especially the life expectancy parameter. Life expectancy in Ambon City in 2017 was the highest among the regencies. This means that people have a longer chance to work and can increase their productivity. Ambon city also has a good quality of health sector. In 2017, Ambon City also had the lowest rate of infant mortality, equal to $0.00 \%$ (Aulele et al. 2017). Ambon City had the highest value in terms of mean years and expected years of schooling in Maluku Province, which indicates a high quality of education in Ambon. A high quality of education can influence the mindset and improve individual insight in solving problems. Ambon City's per capita expenditure was also the highest compared with the other regencies. This shows that the economic capacity of Ambon City is better than the other regencies. 
TABLE 9. The calculation for the life expectancy indicator.

\begin{tabular}{lccccccccccccc}
\hline PCE & WSM & SeM & CM & B & Al & WS & ES & SwM & SB & A & TC & Weight & Calculation result \\
\hline WSM & 1 & 0.5 & 0.333 & 0.333 & 1 & 2 & 4 & 2 & 0.3 & 0.143 & 0.5 & 0.045 & $\lambda$ max \\
SeM & 2 & 1 & 0.5 & 0.5 & 2 & 3 & 6 & 3 & 0.5 & 0.2 & 1 & 0.074 & 11.776 \\
CM & 3 & 2 & 1 & 1 & 4 & 5 & 7 & 4 & 1 & 0.25 & 2 & 0.122 & Cl \\
B & 3 & 2 & 1 & 1 & 4 & 5 & 8 & 4 & 1 & 0.25 & 2 & 0.123 & 0.073 \\
Al & 1 & 0.5 & 0.25 & 0.25 & 1 & 2 & 4 & 2 & 0.3 & 0.125 & 0.5 & 0.043 & 0.077 \\
WS & 0.5 & 0.333 & 0.2 & 0.2 & 0.5 & 1 & 2 & 1 & 0.2 & 0.111 & 0.3 & 0.025 & \\
ES & 0.25 & 0.167 & 0.143 & 0.125 & 0.3 & 0.5 & 1 & 0.333 & 0.1 & 0.111 & 0.2 & 0.015 & CR \\
SWM & 0.5 & 0.333 & 0.25 & 0.25 & 0.5 & 1 & 3 & 1 & 0.3 & 0.125 & 3 & 0.043 & 0.051 \\
SB & 3 & 2 & 1 & 1 & 3 & 5 & 7 & 4 & 1 & 0.25 & 2 & 0.118 & \\
A & 7 & 5 & 4 & 4 & 8 & 9 & 9 & 8 & 4 & 1 & 5 & 0.324 & Consistency \\
TC & 2 & 1 & 0.5 & 0.25 & 2 & 4 & 6 & 0.333 & 0.5 & 0.2 & 1 & 0.068 & $5 \%$ \\
Totals & 23.25 & 14.83 & 9.176 & 9.158 & 26 & 37.5 & 57 & 29.67 & 9.3 & 2.765 & 17 & & LE Weight 0.574 \\
\hline
\end{tabular}

TABLE 10. Development priority class limits.

\begin{tabular}{ll}
\hline PC Class & Value \\
\hline Low & $0.2044-0.2895$ \\
Middle & $0.1193-0.2044$ \\
High & $0.0343-0.1193$ \\
\hline
\end{tabular}

The highest rate of development priority was in East Seram. East Seram had the lowest value in terms of life expectancy and second-lowest mean years of schooling. Research by Hidayaningsih et al. (2011) showed that East Seram was also ranked among the lowest 20 districts in an Indonesian Public Health Development Index (IPHDI) calculation. Life expectancy is calculated by birth rate. In 2017, East Seram had the highest infant mortality, equal to $0.10 \%$ (Aulele et al. 2017). One of the causes could be a lack of clean water. Water is an essential thing for human life; however, access to clean water for the people of East Seram is still very low. The percentage of people using clean water in East Seram (in 2017) was the lowest, equal to 30.87\% (Aulele et al. 2017).

East Seram and West Seram are regencies with the highest levels of illiteracy. These regencies are inhabited by isolated, tribal peoples such as the "Nanunu". The Nanunu Tribe is the largest tribe living in East Seram, and most of its members are still illiterate (Sangadji 2014). In addition, the infrastructure and resources for education, such as the number of schools and teachers, in East Seram are still low.

\subsection{Increasing human development index}

One of the ways to increase the HDI of Maluku is by developing a fiscal policy instrument, where basic service provision is carried out through a budget mechanism. Research by Mahulauw et al. (2016) revealed that Maluku Government expenditure in the health and education sectors, as well as in infrastructure, during the 2009-2013 period showed a positive and significant influence on its HDI.

Reducing inequality and improving welfare are both needed in order to increase public health and education in this area. Spending on education is a long-term investment that can increase knowledge and mindsets. The knowledge, skills, behavior, and moral values of each individual can improve their competitiveness and value of the organization (Rafiei and Davari 2015). Inhabitants' quality in all regencies,

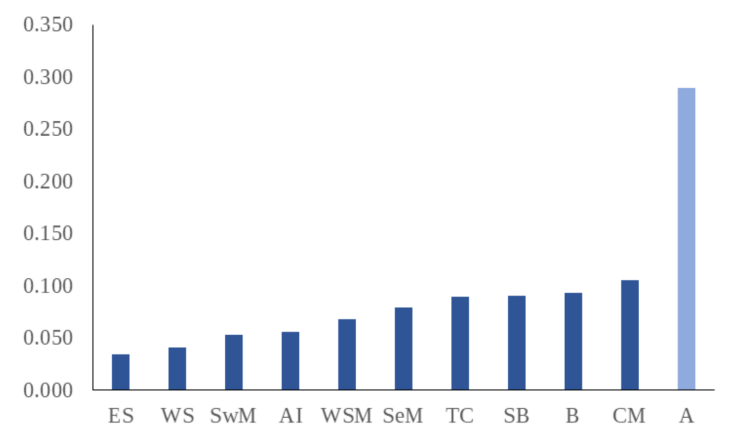

FIGURE 2. Result of development priority determination in Maluku.

but especially in East Seram, will be better if their education quality is increased.

A high development priority was found for 10 of the regencies in Maluku Province, with Ambon City being the sole. This gap could be caused by physical factors from the province itself. These ten regencies were spread on each small island and some areas were dominated by forests. Settlements, which are one of the indicators for development in these 10 regencies, are mostly located in coastal areas so that the proportion between developed and undeveloped areas is not balances. Maluku Province needs more attention from the government and integrated development will reduce inequality.

\section{CONCLUSIONS}

Human quality development in Maluku Province should be focused on regencies that were classified as high priority areas, including Buru, Southeast Maluku, Central Maluku, Aru Islands, West Seram, East Seram, Southwest Maluku, Tual City, and South Buru. Ambon City is an area with low priority because it has the best values across the studied criteria. High priority regencies had 0.0343-0.1193 AHP values, whereas the low priority Ambon City had 0.20440.2895 AHP values.

The human development index level is influenced by equality, sustainability, and development empowerment. There was high inequality in Maluku Province because the only regency that had a low development priority was Ambon. In contrast, the other regencies were not categorized even within a medium development priority; all were found 


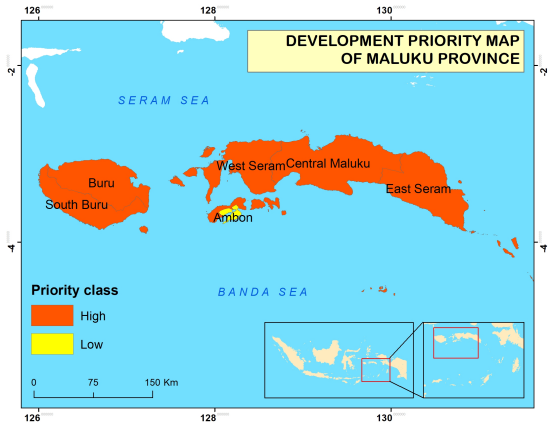

(a)

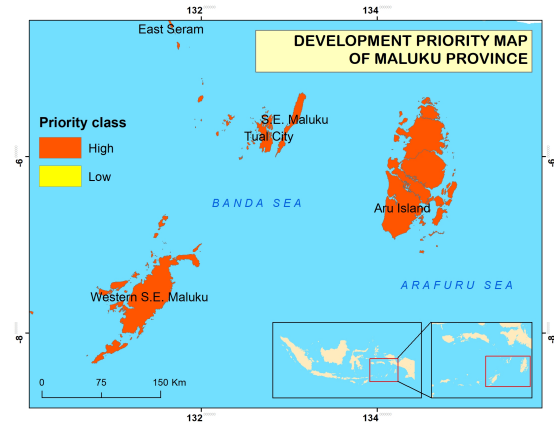

(b)

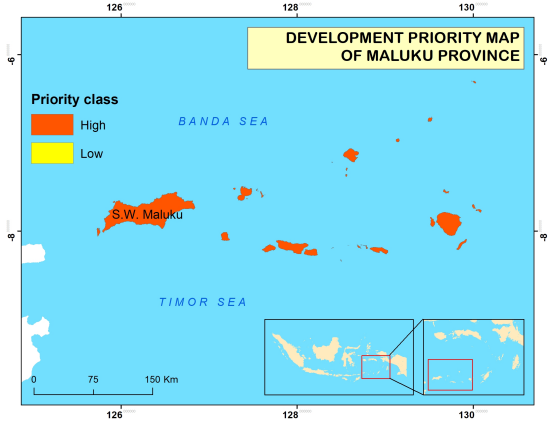

(c)

FIGURE 3. Development priority in: (a) Northern Maluku Province; (b) Western Maluku Province; and (c) Southern Maluku Province.

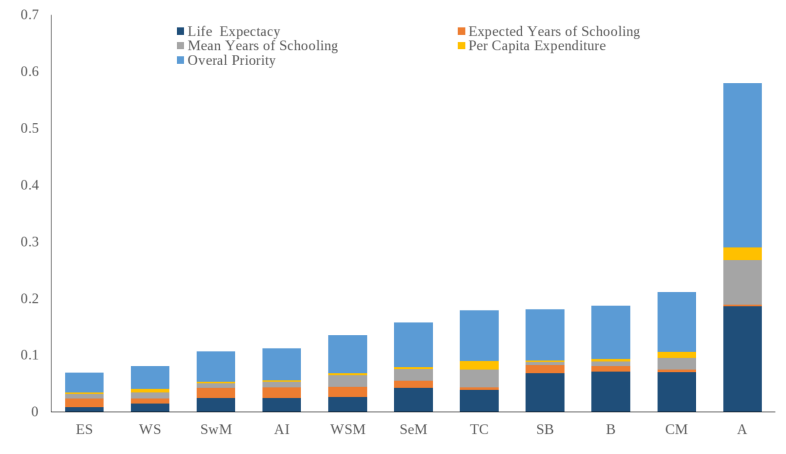

FIGURE 4. Value of life expectancy, mean years of schooling, expected years schooling, and per capita expenditure all regencies in Maluku Province.

to have high development priorities. Although Ambon City is not as wide as the other regencies, its development was the most progressive, something that could be caused by its position as the capital city of Maluku Province. Other regions might be large in terms of land area, but their development has not been progressive enough. Furthermore, the proportion between settlement and forest or wasteland is not balanced enough.

Reducing Maluku Province's inequality from its human quality is very important. Human quality such as healthiness could be increased by improving public health and education to reduce inequality and improve welfare. Increasing the fiscal policy instrument into a smaller scale one than before may also be beneficial, because every regency might then have a character.

\section{ACKNOWLEDGMENTS}

This paper was developed based on the author's work on human and economic resource analysis courses. We would like to thank the Department of Environmental Geography, Universitas Gadjah Mada, Yogyakarta, for the guidance. Special thanks to both the National and Maluku Province branches of Statistics Indonesia for their data availability. Also, many thanks to the reviewers of this article for their helpful advice.

\section{REFERENCES}

Aulele SN, Wattimena AZ, Tahya C. 2017. Analisis regresi multiivariat berdasarkan faktor-faktor yang mempengaruhi derajat kesehatan di Provinsi Maluku [Multivariate regression analysis based on factors affecting health care in Maluku Province]. Jurnal Ilmu Matematika dan Terapan. 11(1):39-48.

Brunelli M. 2015. Introduction to the analytic hierarchy process. New York: Springer, Cham. doi:10.1007/978-3-31 9-12502-2.

Darko A, Chan APC, Ameyaw EE, Owusu EK, Pärn E, Edwards DJ. 2018. Review of application of analytic hierarchy process (AHP) in construction. Int J Const Manage. 19(5):436-452. doi:10.1080/15623599.2018.1452098.

Finkelstein A, Luttmer EFP, Notowidigdo MJ. 2013. What good is wealth without health? the effect of health on the marginal utility of consumption. J Eur Econ Assoc. 11:221-258. doi:10.1111/j.1542-4774.2012.01101.x.

Hanushek EA. 2011. The economic value of higher teacher quality. Econ Educ Rev. 30(3):466-479. doi:10.1016/j.ec onedurev.2010.12.006.

Hardianto AM, Tjahjadi B, Narsa IM. 2018. Human Development Index (HDI) as a planning plan for dealing globalization of ASEAN Economic Society (MEA) in Indonesia. Proceedings of the ICECRS. 1(2):108-115. doi:10.21070 /picecrs.vli2.1444.

Hidayaningsih P, Hapsari D, Ma'ruf N. 2011. Formulation of Indonesian public health development index. Buletin Penelitian Sistem Kesehatan. 14(2):126-135.

Jain P, Jain P. 2016. Population and development: impacts on environmental performance. Chin J Popul Res Environ. 14(3):208-214. doi:10.1080/10042857.2016.1215824.

Mahulauw AK, Santosa DB, Mahardika P. 2016. Pengaruh pengeluaran kesehatan, pendidikan, dan infasruktur untuk meningkatkan indeks pembangunan manusia di Provinsi Maluku [Influence of spending, health, education, and infrastructure for increasing human development index in Maluku Province]. Jurnal Ekonomi Pembangunan. 4(2):122-148.

Mohanty AK, Nayak NC, Chatterjee B. 2016. Does infrastructure affect human development? Evidences from Odisha, India. J Infrastruct Dev. 8(1):1-26. doi:10.1177/ 0974930616640086.

Mu E, Pereyra-Rojas M. 2017. Practical decision making: an introduction to the Analytic Hierarchy Process (AHP) using super decisions V2. New York: Springer, Cham. doi:10.1007/978-3-319-33861-3_2.

Nevima J, Kiszova Z. 2017. Modified human development index and its weighted alternative - the case of visegrad four plus Austria and Slovenia. Forum Sci Oeconomia. 5(2):101-111.

Putri RF, Wibirama S, Giyarsih SR, Pradana A, Kusmiati Y. 2019. Landuse change monitoring and population density analysis of Penjaringan, Cengkareng, and 
Cakung urban area in Jakarta Province. E3S Web Conf. 76:03004. doi:10.1051/e3sconf/20197603004.

Putri RF, Wibirama S, Sukamdi, Giyarsih SR. 2018. Population condition analysis of Jakarta land deformation area. IOP Conf Ser: Earth Environ Sci. 148:012007. doi: 10.1088/1755-1315/148/1/012007.

Rafiei N, Davari F. 2015. The role of human resources management on enhancing the teaching skills of faculty members. Materia Socio Medica. 27(1):35-38. doi: 10.5455/msm.2014.27.35-38.

Saaty TL. 2012. Decision making for leaders: the analytic hierarchy process for decisions in a complex world. 3rd edition. Pittsburgh: RWS Publications.

Sangadji M. 2014. Analisis faktor-faktor yang mempengaruhi kemiskinan di Provinsi Maluku [Analysis of factors that influence poverty in maluku province]. Media Trend. 9(2):162-180. doi:10.21107/mediatrend.v9i2.776.

Sipahi S, Timor M. 2010. The analytic hierarchy process and analytic network process: an overview of applications. Manage Decis. 48(5):775-808. doi:10.1108/0025174101 1043920.

Statistics Indonesia. 2017. Potret kondisi sosial ekonomi Provinsi Kepulauan Riau 2017 [Portrait of the socioeconomic conditions of Riau Province in 2017]. Jakarta:
Statistics Indonesia.

Statistics Indonesia. 2018a. Maluku data 2017 (new method). Jakarta: Statistics Indonesia; [accessed 2018 Nov 20]. ht tps://ipm.bps.go.id/data/provinsi/metode/baru/81 00 .

Statistics Indonesia. 2018b. Profil kemiskinan di Indonesia Bulan Maret Tahun 2018 [Indonesia's poverty profile in March 2018]. Ambon: Statistics Indonesia.

Tsaurkubule Z. 2014. Influence of quality of life on the state and development of human capital in Latvia. Contemp Econ. 8(1):103-112. doi:10.5709/ce.1897-9254.134.

[UNDP] United Nations Development Programme. 2015. Training material for producing national human development reports - the multidimensional poverty index (MPI). Technical Report March. UNDP (Human Development Report Office).

Yakunina R, Bychkov G. 2015. Correlation analysis of the components of the human development index across countries. Procedia Econ Finance. 24:766-771. doi:10.1 016/s2212-5671(15)00692-9.

Yilmazer M, Çinar S. 2015. Human capabilities and economic growth: a comparative human capability index. Int J Econ Financ Issues. 5(4):843-853. 